Accepted manuscript Helfenstein et al. (2020) https://doi.org/10.1016/bs.aecr.2020.08.005 1

This document is the accepted manuscript version of the following article:

Julian Helfenstein ${ }^{1, *}$, Vasco Diogo ${ }^{2}$, Matthias Bürgi ${ }^{2}$, Peter Verburg ${ }^{2,3}$, Rebecca Swart ${ }^{3}$, Franziska Mohr ${ }^{2,4}$, Niels Debonne ${ }^{3}$, Christian Levers ${ }^{5,6,7}$, Felix Herzog ${ }^{1}$

\title{
Conceptualizing pathways to sustainable agricultural intensification
}

Advances in Ecological Research. Publisher DOI: https://doi.org/10.1016/bs.aecr.2020.08.

$\underline{005}$

This manuscript version is made available by the CC-BY-NC-ND 4.0 license

http://creativecommons.org/licenses/by-nc-nd/4.0/

Originally uploaded to https://www.agroscope.admin.ch/agroscope/de/home/

publikationen.html on 22 September 2020

${ }^{1}$ Agroscope, Zürich 8046, Switzerland

${ }^{2}$ Land Change Science Research Unit, Swiss Federal Research Institute WSL, 8903 Birmensdorf, Switzerland

${ }^{3}$ Environmental Geography Group, Institute for Environmental Studies (IVM), Vrije Universiteit Amsterdam, 1081 HV Amsterdam, The Netherlands

${ }^{4}$ Institute of Geography, University of Bern, Bern 3012, Switzerland

${ }^{5}$ School of Public Policy and Global Affairs, University of British Columbia, 1855 West Mall, Vancouver, British Columbia V6T 1Z2, Canada

$4{ }^{6}$ Department of Computational Landscape Ecology, Helmholtz Centre for Environmental Research - UFZ, Permoserstr. 15, 04318 Leipzig, Germany

${ }^{7}$ Institute for Resources, Environment and Sustainability (IRES), University of British 7 Columbia, 2202 Main Mall, Vancouver, British Columbia V6T 1Z4, Canada 
Submitted manuscript Helfenstein et al. (2020) https://doi.org/10.1016/bs.aecr.2020.08.005 2

*Corresponding author: julian.helfenstein@agroscope.admin.ch

30

31

32

33

34

35

36

37

38

39

40

42

43

44

45

46

47

48

49

50

51

52

53

54

55

\section{Abstract}

There is widespread consensus among scientists, policy makers, and practitioners that agriculture should become more sustainable, while maintaining the ability to meet future food demand. However, there are still many diverging views on what sustainable intensification means, and how to get there. In this article, we present a conceptual framework to navigate agricultural intensification pathways. The conceptual framework aligns three research themes central to improving the sustainability of agriculture: 1) What are the social, economic, and environmental trade-offs of alternative agricultural intensification options? 2) How do land managers decide on intensification strategies, and how can the adoption of sustainable practices be made more attractive? 3) How do socio-political, technological, and environmental mega-trends and other drivers of change affect sustainable intensification measures and agricultural landscapes? The framework presented here goes beyond earlier frameworks by considering multiple dimensions of intensity and sustainability, drawing from both natural and social science theories. Also, it operates across spatial and temporal scales, and is outcome-focused while explicitly considering the linkages between decision making processes and sustainability outcomes. We argue that given these novelties the conceptual framework can serve as a blueprint to assess pathways towards sustainable agricultural intensification. 
Submitted manuscript Helfenstein et al. (2020) https://doi.org/10.1016/bs.aecr.2020.08.005 3

56

57 Keywords: land use, ecological intensification, sustainable agriculture, agricultural 58 development, sustainability assessment, nature's contributions to people, landscape 59 approach, decision making processes, food security 60 
61

62

\section{Introduction}

As a whole, future agricultural landscapes must meet three major global challenges. Firstly, they must feed a growing world population, which, if global dietary trends and food losses and waste patterns are not transformed considerably, translates to increasing food production by $50 \%$ by 2050 (Godfray et al., 2010; Searchinger et al., 2018; Xavier, 2018). Secondly, negative impacts of agricultural landscapes must be reduced to prevent irreparable damage to Earth system functioning (Díaz et al., 2019; Steffen et al., 2015). Thirdly, livelihoods of farmers and associated communities must be aligned with food security and environmental goals (Caron et al., 2018). Meeting these multiple challenges will require profound changes to food production systems in the coming decades.

Scientists have proposed the concept of sustainable intensification as a pathway to address the challenge of aligning production goals with environmental goals (Pretty, 1997). Sustainable intensification is often defined as management, planning or technological adaptations that increase agricultural production while decreasing negative impacts on the environment (Pretty et al., 2011; Rockström et al., 2017; Struik et al., 2014; Weltin et al., 2018). While early definitions of sustainable intensification focused on reducing yield gaps and environmental costs, the term has become broader in order to accommodate the multiple dimensions of agricultural intensity and sustainability (Struik and Kuyper, 2017; Vanbergen et al. this volume). Due to the promise of win-win solutions, sustainable intensification has found considerable uptake not only by the scientific community but also by policy makers in the United Nations, the European Union, China and the United States as well as the private sector (Chen et al., 2014; Janker et al., 2018; Tittonell, 2014; Weltin et al., 2018). However, several issues have been pointed out with current conceptualizations of sustainable intensification. Addressing those issues is the main motivation for this article. 
Agricultural intensity is typically characterized by the type and amount of inputs and outputs, as well as the system's efficiency of converting inputs into outputs (Erb et al., 2016). In this notion, intensification means enhancing outputs through increased inputs (such as fertilizer) or increasing system efficiency (such as improved cultivars) (Erb et al., 2013; Kuemmerle et al., 2013). This conception captures the agronomic dimension of intensification at the field or farm scale. However, intensification strategies may also imply interventions at the landscape level, such as landscape simplification through removal of trees, hedgerows and other elements, often with impacts on habitat fragmentation, ecosystem functioning and biodiversity (Emmerson et al., 2016; Gámez-Virués et al., 2015; Malaj et al., 2014; Oehri et al., 2020; Stoate et al., 2009; Vanbergen et al. this volume). In addition, while regional strategies such as land sharing and land sparing (Grass et al. this volume) are operationalized at the landscape level (Weltin et al., 2018), landscape-scale processes are not typically included in existing land use intensity frameworks (Erb et al., 2013; Kuemmerle et al., 2013).

Another key shortcoming of the current sustainable intensification debate is the neglect of the social dimension of sustainability (Janker et al., 2019; Struik and Kuyper, 2017; Skrimizea et al. this volume). While the global political discourse on sustainable intensification is primarily dominated by how to increase production and the scientific discourse has mostly focused on reducing environmental impacts, social dimensions have received little attention from both sides (Janker et al., 2018; Rasmussen et al., 2018). This implies that the potential effects on farmers' well-being and livelihoods are often neglected. With rising societal and political pressure, farmers worldwide are increasingly overwhelmed and discontented, leading to farmer protests or suicides (Singh et al., 2020; Stokstad, 2019). There is potential for societal conflicts to arise and lead to change during the transition to a sustainable agriculture (Skrimizea et al this volume). Improving livelihoods of farmers and associated rural communities and understanding their values and needs must be included alongside environmental and food security goals (Andres and Bhullar, 2016; Janker et al., 2019) to 


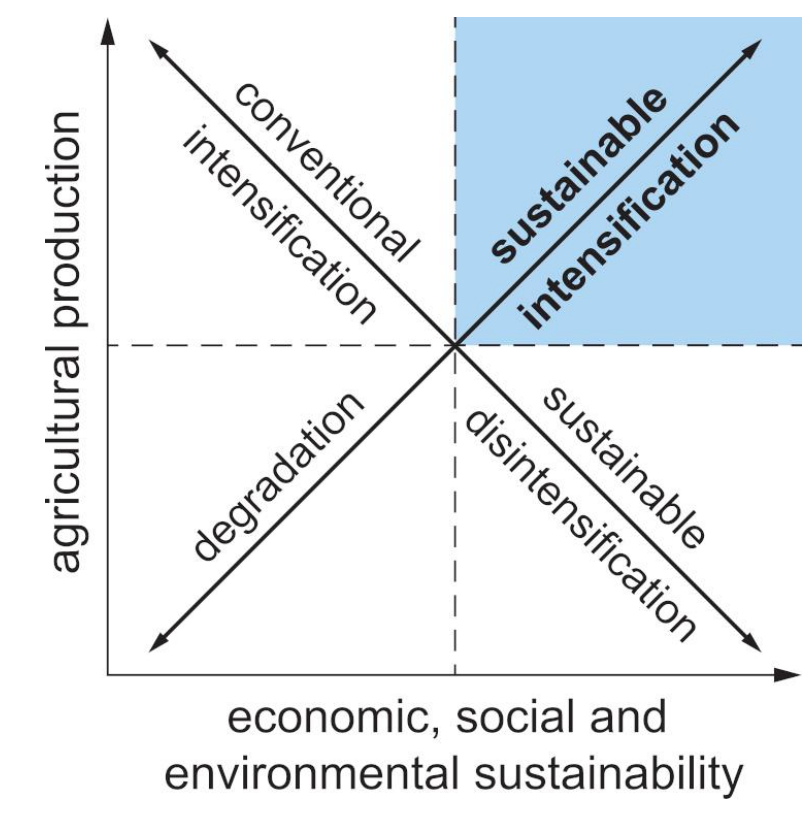

ensure that the social dimension is integral to assessments of and the transition to sustainable agricultural intensification.

Agronomic measures to increase productivity at plot and farm-level still dominate the sustainable intensification discussion (Pretty et al., 2011; Smith et al., 2017; Weltin et al., 2018). However, it has been shown that in order to assess sustainability, cumulative effects of individual farm level decisions as well as inter-relations across space and time must be considered (Adger et al., 2009; Prestele and Verburg, 2019). This includes processes that act across large distances, i.e. through trade and displacement of production and environmental impacts. For example, in Europe, livestock feed and other biomass-based products are increasingly imported from abroad, leading to important land-related sustainability issues such as deforestation in South America (Haberl et al., 2016). Agricultural intensification may also lead to a "Jevons paradox", when the benefits from increased productivity make land conversion more profitable, leading to further expansion of agricultural land rather than the expected decrease that would occur under constant production (Ceddia et al., 2013; Meyfroidt et al., 2018). Therefore, the conception of sustainable intensification needs to consider explicitly the various scales of drivers leading to land use change as well as the outcomes of these changes. 
Submitted manuscript Helfenstein et al. (2020) https://doi.org/10.1016/bs.aecr.2020.08.005 7

Figure 1. Pathways of agricultural development. Sustainable intensification is a development where both agricultural production and sustainability are increased.

Devising sustainable intensification pathways requires anticipating, quantifying and balancing both market and non-market outcomes. In addition to agricultural production, a broad range of economic, environmental, and social sustainability effects must be considered. Due to this complexity, rather than being clearly sustainable or not sustainable, all intensification pathways are likely to come with trade-offs (Kay et al., 2018). Assessing the sustainability of these trade-offs is, in the end, a normative judgement, which depends on the prevailing societal value systems of the affected stakeholders (Struik et al., 2014). Nevertheless, science has a crucial role in creating and reflecting upon such visions of sustainability (Schneider et al., 2019). This means research on sustainable intensification should focus on the multiple outcomes of such pathways, and present trade-offs in land use decisions in a transparent way.

The objective of this article is to develop a conceptual framework to guide scientists through the daunting task of analyzing pathways of sustainable agricultural intensification. In this article we define sustainable intensification as an agricultural development pathway that entails both benefits to sustainability and to agricultural production. We present sustainable intensification in relation to other development pathways that benefit only agricultural production (conventional intensification), only sustainability (sustainable disintensification), or lead to a degeneration of both (Fig. 1). Our proposed framework covers the multiple dimensions of both land use intensity and sustainability, operates across spatial and temporal scales, and focuses on outcomes to inform societal debates. Existing conceptual frameworks are often focused on specific research questions or components of the concept of sustainable intensification. Therefore, in this article, we will first review existing frameworks and theories relevant for sustainable intensification. We then build upon those by integrating existing approaches to develop a new conceptual framework for assessing sustainable 
Submitted manuscript Helfenstein et al. (2020) https://doi.org/10.1016/bs.aecr.2020.08.005 8

163

164

165

intensification pathways. Finally, we will show potential applications of the conceptual framework in light of key research themes central to improving the sustainability of agriculture.

\section{Existing frameworks and theories underpinning}

\section{conceptualization of sustainable intensification}

We draw from four research fields to meet the requirements of a conceptual framework that can assess the sustainability of pathways of agricultural intensification, and these are briefly reviewed in this section. Land system science is the study of human interactions with the natural environment (Verburg et al., 2013), and as such provides a theoretical umbrella for assessing sustainable intensification. We also draw from the landscape approach to account for the need to explicitly consider the landscape scale and its effects in a sustainability assessment. To explain and predict agricultural development pathways, we bring in decision making processes and theory. And finally, we review nature's contributions to people (NCP) as a conceptual instrument to assess sustainability outcomes over multiple sustainability dimensions and value systems (Díaz et al., 2018).

\subsection{Land systems as a theoretical umbrella for assessing sustainable intensification}

Land system science is a maturing field of knowledge that combines concepts and methods from different disciplinary traditions (e.g. geography, landscape ecology, economics) for monitoring and describing patterns of land-cover change, explaining the drivers of decisionsmaking processes leading to land-use change, and understanding the linkages between these two (Meyfroidt et al., 2018; Verburg et al., 2015). The field has produced a wide range of conceptualizations and theories, backed by empirical work at all spatial scales. As this body of knowledge is yielding more and more generalizable knowledge, the field is increasingly instrumental in progressing understanding of land dynamics, the potential of 
190

land-related policies, and the projection of future land system dynamics (Magliocca et al., 2018; Meyfroidt et al., 2018).

Agricultural land-use changes are manifested through a multitude of processes, such as the expansion or contraction of agricultural land areas, changes of management intensity, landuse activity and landscape structure, and farm specialization/diversification) (van Vliet et al., 2015). Changes in agricultural landscapes are frequently driven by a combination of economic, technological, institutional and location factors (Bürgi et al., 2005; Levers et al., 2016; Plieninger et al., 2016). These factors may affect farmer decisions differently depending on farmer types, according to their abilities and attitudes (van Vliet et al., 2015). The increasing role of globalized markets, decisions by distant governments and investors, and global agenda setting have recently led to an increased attention to cross-scale, causal interactions and feedbacks between distant human-environmental systems, i.e. how land-use changes in one location affect and are affected by developments somewhere else (Eakin et al., 2014; Liu et al., 2013).

Multiple theories of land-use intensification have been proposed, the application of which depends on place- and actor-specific contexts such as the degree of integration in markets and the reliance on labor in relation to capital inputs (for a review see (Meyfroidt et al., 2018)). Based on these theories, Erb et al. (2013) proposed a generalized framework for conceptualizing and measuring land-use intensity. This and related frameworks consider the use and substitution effects of inputs (labor, land, capital), which go into the production system to yield outputs, and these three elements affect and are affected by system properties that also drive system outcomes (Erb et al., 2013; Kuemmerle et al., 2013). Such frameworks provide a systematic perspective of intensification processes, including tradeoffs, synergies and feedback loops between agricultural production and changes in land system properties. However, its focus on the input and output properties of production systems implies that interventions on landscape structure, and related impacts in terms of 
ecosystem functioning, are not fully addressed. Furthermore, this framework also fails to consider social impacts (Skrimizea et al this volume) that are not directly related to material, financial or energy flows and accounts. Finally, it does not explicitly consider the motivations behind the decision-making processes leading to intensification of land use, nor the way these decisions are influenced by different drivers. Hence existing land use intensity frameworks need to be adapted to the explicitly cross-scale, multi-objective challenge of assessing agricultural intensification pathways.

\subsection{The landscape approach for integrating multiple objectives}

The landscape approach has been developed to address social, economic and environmental goals in multi-stakeholder areas. The term "landscape approach" is often used inter-changeably with "ecosystem approach" and refers to "any spatially-explicit attempt to simultaneously address multiple objectives", such as development and conservation (Sayer et al., 2013). Key principles of the landscape approach are multiple scales, multiple stakeholders, and multifunctionality (Sayer et al., 2013). The advantages of the landscape approach are co-consideration of biophysical and socio-economic components and processes at multiple scales, providing the potential to overcome sectoral approaches that have in the past hindered finding solutions to complex land use challenges (Bürgi et al., 2017a). While originating from the field of biodiversity conservation in the 1980s (Noss, 1983), the landscape approach has been continuously adapted to integrate socio-economic dimensions (Collins et al., 2011; Sayer et al., 2013). More recently, the landscape approach has been used to address often conflicting goals of biodiversity conservation and economic development (Pfund, 2010), carbon sequestration and food production (DeFries and Rosenzweig, 2010), and the UN Sustainable Development Goals in general (Bürgi et al., 2017a).

A landscape approach for evaluating the sustainability of agriculture is advantageous because many outcomes of agricultural practices are best assessed at the landscape scale 
246 (Kleijn et al., 2019; Tscharntke et al., 2005; Van Zanten et al., 2014). While agricultural 247 productivity can be measured at the field or farm scale, non-market outcomes such as

248 biodiversity conservation or landscape aesthetics are dependent on landscape structure 249 (Kleijn et al., this volume). In the agricultural context, landscape structure denotes fields and 250 landscape elements and their positioning in space, thus encompassing field sizes, crop 251 diversity, proportion of semi-natural habitats, etc. (Baessler and Klotz, 2006; Herzog et al., 252 2006; Levers et al., 2016). Landscape structure goes beyond land cover to also 253 accommodate other common metrics for spatial pattern and structure (Taylor et al., 1993; 254 Thies and Tscharntke, 1999). The importance of landscape structure for non-market 255 outcomes can be seen, for example, in the dramatic decline in insect abundances in 256 Germany, which was shown to relate to the share of arable land in the surrounding 257 landscape (Seibold et al., 2019). Similarly, social dimensions of land system outcomes, such 258 as landscape perception are dependent on spatial patterns as well as management intensity 259 (Junge et al., 2015; Schüpbach et al., 2020). The landscape approach is thus useful to address the multiple objectives, scales and stakeholders of research questions revolving 261 around sustainable intensification pathways.

262

\subsection{Understanding farmers using the theory of planned behavior}

As land use decisions towards sustainable intensification are taken by individual farmers, organizations such as agricultural cooperatives, industry (i.e. supermarkets, agribusiness) or institutions, the role of decision making in these processes is key to understanding the

267 adoption and incentives that underlie changes in land use and management. Although there 268 are different frameworks and theories helping to frame and understand such decision making 269 (Schlüter et al., 2017), the theory of planned behavior has proven particularly versatile to 270 capture the complexity of human decision-making (Fielding et al., 2008; Malek et al., 2019; 271 Sereke et al., 2016). The theory states that attitude, subjective norm, and perceived behavioral control lead to intention, which may in turn lead to behavior (i.e. a land use 
274

275

276

277

278

279

280

281

282

283

284

285

286

287

288

289

290

291

292

293

294

295

296

297

298

299

300

301

expected outcomes of the behavior. Subjective norm is produced by beliefs about the normative expectations of others and the perceived behavioral control is formed by control beliefs that enable or hinder performance of the behavior (Fishbein and Ajzen, 2010). In other words, decision-making is not simply the result of rational, economic valuation (rational choice theory or bounded rationality), but includes both well-considered and unprompted decision-making.

While in many studies rational actor models, often informed by economic calculations, are still dominant, they are gradually supplanted with more complex human behavior models accounting for more complex decision making processes (Müller-Hansen et al., 2017; Schlüter et al., 2017). Rational actor models neglect differences in human attitude and perception, and thus leave out an important component driving agricultural land use decisions (Baumgart-Getz et al., 2012). Research on understanding decision making often involves surveys that try to grasp the behaviors and underlying attitudes, subjective norms, perceived control and intent. For example, interviews with Swiss farmers to understand adoption of agroforestry showed that the most important driver for non-adoption was farmers' fear of losing their reputation (Sereke et al., 2016), while a study on adoption of soil erosion control practices in Belgium revealed that the most important variable was farmers' attitude towards soil conservation practices (Wauters et al., 2010). Also, in simulation models of land use decision there is a trend to move away from only considering external drivers towards focusing on internal drivers of human decision making (Groeneveld et al., 2017; Huber et al., 2018). Tying decision making processes in a land system conceptualization of sustainable intensification would help to understand how land use decisions are made, and what barriers need to be addressed to move agricultural landscapes in the desired direction.

\subsection{Assessing trade-offs using nature's contributions to people}

Nature's contributions to people (NCP) are the "contributions, both positive and negative, of living nature to people's quality of life" (Díaz et al., 2018). NCP and the older term ecosystem 
services have become widely used because they show how healthy ecosystems are important for human well-being (Díaz et al., 2019; Millennium Ecosystem Assessment, 2005). NCP resonate with the term ecosystem services, but go beyond the concept of ecosystem services by embracing multiple worldviews (Kadykalo et al., 2019). In this text we will use the term NCP also to describe older studies performed under ecosystem service terminology. NCP comprise instrumental and relational benefits people draw from nature, including climate regulation, water quality regulation, water flow regulation, pollination, food and energy production, soil protection (Pascual et al., 2017). NCP also cover nature's cultural services, thus tying into the social dimension of sustainability. Cultural services include recreation and tourism, aesthetic values, spiritual values, cultural heritage, and sense of place (Díaz et al., 2019; Millennium Ecosystem Assessment, 2005), which are all important for social sustainability. NCP can be assessed at various spatial scales and have been used effectively to illustrate land cover and land use intensity trade-offs in agricultural landscapes (Foley et al., 2005; Helfenstein and Kienast, 2014; Kay et al., 2018), and to visualize trade-offs in agricultural intensification pathways (Garbach et al., 2017; Gunton et al., 2015).

Valuation of NCP links to the economic dimension of sustainability. The field of environmental economics provides a large set of tools to approximate values of otherwise non-marketable goods. These tools include avoided cost (e.g. for natural hazard protection), replacement cost (e.g. for water regulation), travel cost (e.g. for recreation areas), and hedonic pricing (e.g. for landscape aesthetics) (de Groot et al., 2002). Application of these economic tools has made it possible to translate elusive services such as soil protection, groundwater recharge, or carbon sequestration to monetary terms for trade-offs with agricultural production (Kay et al., 2019). Valuation of ecosystem services has also made it possible for land-owners to receive financial compensation for maintaining ecosystem services, a mechanism termed payment for ecosystem services (Engel et al., 2008). Payment for ecosystem services is becoming more established in European agricultural 
policy. In Switzerland, farm subsidies for culturally valuable landscapes, biodiversity conservation, and landscape quality amount to almost one billion Euros annually, and may

332 constitute the main source of income for farmers on less-productive land (BLW, 2019).

333 However, economic valuation of NCP represents only one of many value systems, and the 334 Intergovernmental Platform on Biodiversity and Ecosystem Services (IPBES) has thus 335 336 promoted pluralistic valuation considering all three dimensions of sustainability as well as nature’s intrinsic values (Díaz et al., 2019; Pascual et al., 2017).

To fully grasp value trade-offs of management decisions, NCP must be considered together with intrinsic values of nature and additional indicators for quality of life (Díaz et al., 2015). Neither NCP nor ecosystem services cover non-land-based implications of agricultural land use decisions such as gender issues, equity, safety hazards, future perspectives, or fair pay (Mahon et al., 2017; Mann, 2018; Smith et al., 2017). These purely anthropocentric aspects of quality of life must be considered with additional non-anthropocentric values such as animal welfare and biodiversity (Pascual et al., 2017). In fact, most human societies agree that nature has an intrinsic value, independent of its measurable human use (Díaz et al., 2015). This has been recognized by the IPBES, which proposes that sustainability assessments consider not only NCP but also nature values and quality of life (Díaz et al., 2019, 2015). Hence, NCP provide a powerful tool to assess the sustainability of intensification pathways; however, depending on the context, it may be important to also consider effects on non-land related indicators of economic and social sustainability.

\section{A new framework for sustainable intensification}

Here we present a new conceptual framework for assessing sustainable intensification pathways that integrates land system science perspectives with deeper insights in land manager decision making processes. The framework takes a landscape approach to cover the multiple dimensions of agricultural land use intensity and sustainability and operates across spatial and temporal scales. Nature's contributions to people are used to assess 
sustainability outcomes of land use decisions, making the framework outcome-focused. Also,

359 the framework integrates three main research themes driving the long-term sustainable 360 intensification research agenda (Fig. 2). The general overview of the framework and its 361 rationale are presented in the following paragraphs, while key components are unpacked in 362 more detail in the subsequent section (4).

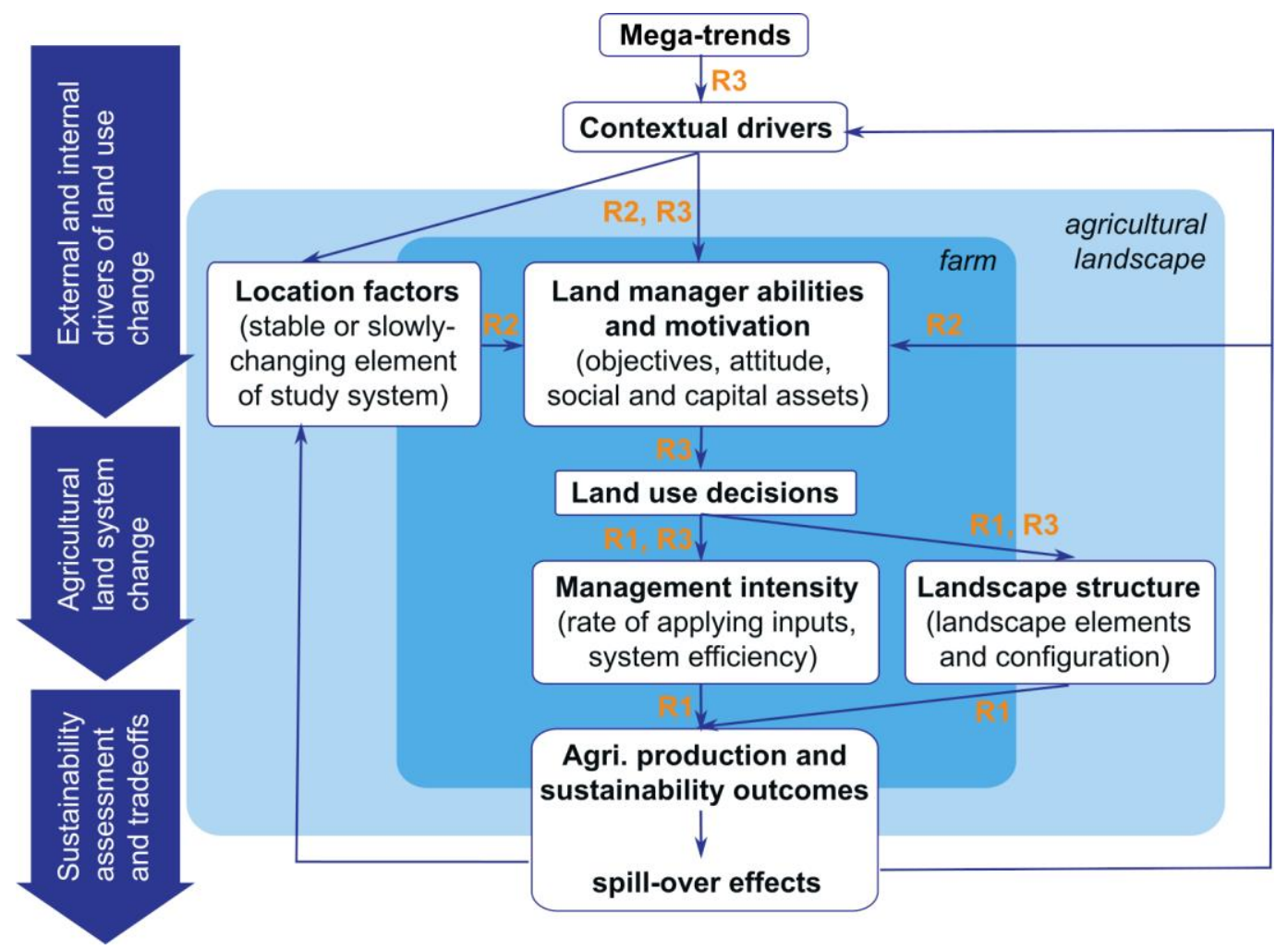

364 Figure 2. Conceptual framework of agricultural intensification and resulting trade-offs across spatial scales. Assessment of sustainable intensification pathways follows three steps. First, analysis of external and internal drivers of land use change. Second, agricultural land systems change. And third, assessing sustainable intensification (SI) outcomes. $R$ 1-3 refer to key research themes for transferring sustainable intensification from theory into practice. R1- what are the sustainability trade-offs of alternative agricultural intensification options? R2- how do land managers decide on intensification practices, and how can the adoption of sustainable practices be facilitated? R3-how do socio-political, technological, and environmental mega-trends affect sustainable intensification measures and agricultural landscapes? 
375 Our conceptual framework is explicitly cross-scale, integrating the farm-scale, the landscape-

376 scale and interrelationships with larger spatial scales (national to global). The farm-scale is

377 central in our framework as the level where land managers, encompassing individual family,

378 corporate and collective farms, make and execute land use decisions (von Haaren et al., 379 2012). Larger spatial scales from national to global levels must also be considered in both 380 assessing the drivers of change as well as in the outcomes. For example, land managers are 381 influenced by global mega-trends through contextual drivers and their interaction with 382 location factors (see Fig. 2), these include processes such as global trade agreements, 383 changes in land governance and policy as well as global climate change. The landscape 384 scale is central for both understanding the context in which a farmer is embedded while 385 making land-use decisions, and assessing the outcomes of these decisions in the form of nature's contributions to people. In addition, spill-over effects at larger spatial scales must be considered in a sustainability assessment and when discussing land use trade-offs. Our framework thus adopts a landscape approach to sustainable intensification by positioning the landscape scale as a bounded nested system to identify and assess agricultural production and sustainability outcomes, while integrating the farm-scale and accounting for impacts from and spill-over effects at larger spatial scales (Bürgi et al., 2017a; Collins et al., 2011; DeFries and Rosenzweig, 2010).

Our conceptual framework covers multiple dimensions of intensity. We adopted the land system science approach to break down land use change into management intensity and landscape structure (see Fig. 2). Management intensity denotes the rate of applying inputs,

397 such as labor, fertilizer, pesticides, and capital, as well as variables related to system 398 efficiency, such as resource use efficiency, harvest index, feed-conversion rates etc. 399 Management intensity here covers the terms input intensity and system efficiency from 400 earlier land use intensity frameworks (Erb et al., 2013; Kuemmerle et al., 2013). Output 401 intensity is another commonly-considered dimension of intensity and this is contained in 402 agricultural production in our framework. Due to landscape structure's importance for 
403

404

405

406

407

408

409

410

411

412

413

414

415

416

417

418

419

420

421

422

423

424

425

426

427

428

429

430

sustainability outcomes and in line with the landscape approach, we expanded existing landuse intensity frameworks to also include landscape structure as a dimension of land use intensity. Hence our conceptual framework covers traditionally considered dimensions of intensity (input, output and system efficiency) and also adds a new dimension, landscape structure, to better address how land use decisions affect sustainability outcomes (Fig.2 Research theme R1).

The conceptual framework integrates social and natural sciences to consider the three dimensions of sustainability. Studies of land system change focus on the monitoring of land use changes, the external drivers and location factors of these changes, and their environmental outcomes (Verburg et al., 2015). However, ultimately land use decisions are made by land managers. To understand how land managers decide to adopt sustainable intensification practices (R2), more sophisticated representation of decision making is essential (Schlüter et al., 2017). Our framework incorporates the theory of planned behavior and acknowledges that external drivers (here contextual drivers and location factors) interact with land managers' abilities and motivation to drive land use decisions (see Fig. 2). This bridges the conceptual models of natural sciences more interested in how mega-trends and drivers affect agricultural land system change (R3), and social sciences that study adoption of sustainable intensification practices (R2), paving the way for a more holistic approach to study sustainable intensification.

Our conceptual framework is outcome focused. This is a deliberate difference to existing land use intensity frameworks, which describe land systems and land system change, rather than assessing the sustainability of intensification pathways (Erb et al., 2013; Kuemmerle et al., 2013). In order to make an informed choice between different intensification options, stakeholders need to know about potential outcomes for human well-being. Therefore, the framework considers how agricultural land system change impacts agricultural production and other sustainability outcomes by borrowing from the concept of nature's contributions to 
431

432

433

434

people, while also accounting for quality of life and intrinsic values of nature. These outcomes are then considered together with spill-over effects and trade-offs at various spatial scales. In line with Fig. 1, outcomes are divided into agricultural production and economic, social and environmental sustainability.

\section{Unpacking the conceptual framework}

This section describes the three analytical steps of the conceptual framework (Fig. 2) in more detail: 1) external and internal drivers of land use change, 2) agricultural land system change, and 3) assessing sustainable intensification outcomes. In our view, the latter is the ultimate goal of the framework, because identifying and assessing the actual sustainability outcomes and trade-offs of alternative pathways is instrumental for informing the societal debate on sustainable intensification. We review the available literature on these subcomponents and provide suggestions on how to operationalize the analytical steps.

\subsection{External and internal drivers of land use change}

Understanding land use change requires analysis of both external and internal drivers. Drivers of land use change have often been studied in a historical context in an effort to explain why current agricultural landscapes appear as they are, or to postulate future drivers of change (Jepsen et al., 2015; Plieninger et al., 2016; van Vliet et al., 2015). These studies typically focus on external drivers, such as political, economic, cultural, technological, and biophysical pressures on land managers, rather than the decision process of individual land managers (internal drivers). In our framework, external drivers are divided into mega-trends, contextual drivers and location factors in a nested format. Mega-trends are transformative trends over prolonged periods of time, such as globalization, digitalization, energytransformation, and climate change (Kienast et al., 2019). Contextual drivers are systemic conditions influencing the conditions under which land use decisions are made (Geist et al., 
2006). These drivers are usually manifested at the regional to national scale, embedded in global mega-trends. Examples of contextual drivers are trade-agreements, environmental and agricultural policy, diet and consumer preferences, access to technology and financing, or introduction of new crop and livestock breeds (Vanbergen et al this volume). The role of external drivers in a study area can be inferred by a combination of methods, including statistical and time-series analysis, simulation models, process tracing, expert knowledge or interviews with local stakeholders (Bürgi et al., 2017b; Meiyappan et al., 2017; Meyfroidt, 2016). In future explorations they are often captured in the storyline of scenarios.

Location factors (called contextual factors by Meyfroidt (2016)) are stable or slowly changing elements of the study system (Meyfroidt, 2016). Location factors include a combination of socio-economic and biophysical drivers that is unique to each place, such as accessibility and available infrastructure, labor supply, climate, soil quality, topography, socio-cultural norms and institutions (Bürgi et al., 2017b; Meiyappan et al., 2017; van Vliet et al., 2015). These factors usually remain stable over years to decades, unless triggered by sudden changes in contextual drivers. Like contextual drivers, location factors are outside the direct control of land managers, but unlike contextual drivers, they are within the system boundary. Often drivers interact with location factors. For example, globalization has led to intensification of agriculture in areas with favorable location factors such as good accessibility and infrastructure, favorable terrain and favorable climate or access to irrigation (Levers et al., 2018). However, in areas of poor infrastructure, low labor supply, unfavorable climate, or rough topography, globalization has led to land abandonment (Jepsen et al., 2015; Meiyappan et al., 2017; Prishchepov et al., 2013).

Location factors often directly determine the abilities of the farmer, but can also play an important role in the motivation of the farmer, i.e. through specific incentives. The abilities of a land manager include the availability of human, social, financial, physical and natural capital. Motivation includes the attitude and objectives, the subjective norm, as well as the 
perceived behavioral control. In combination, those factors lead to what Schmitzberger et al. (2005) called farming styles. In terms of operationalization, the abilities and motivation of land managers can be probed in questionnaires. A practical approach to deal with the large breadth of farmers is to define farmer typologies based on decision-trees (Darnhofer et al., 2005) or, for larger datasets, clustering algorithms (Malek et al., 2019). These farmer typologies can then be the basis for agent-based modeling to predict the adoption or nonadoption of sustainable intensification approaches (Daloğlu et al., 2014; Valbuena et al., 2008).

\subsection{Agricultural land system change}

Analysis of agricultural land system change is divided into the study of management intensity and landscape structure. In our conceptual framework, management intensity covers the rate of applying inputs and the system efficiency. The rate of applying inputs is perhaps the most studied component of land use intensity, often called input intensity, and is what people understand when they think of intensity at the field-level (Emmerson et al., 2016; Herzog et al., 2006; Mahon et al., 2017; Smith et al., 2017; Weltin et al., 2018). Most studies focus on the intensity of fertilizer and pesticide applications, but input intensity can also be extended to include energy investment, labor and capital inputs, and water use (Erb et al., 2013). For example, in arid environments, conversion from rain-fed to irrigated agriculture is a common form of intensification. If irrigation infrastructure is later made more water or energy efficient, e.g. converted to drip irrigation, this may be a form of sustainable intensification (Weltin et al., 2018). In livestock systems, input intensity includes feed concentrate and antibiotic inputs (Smith et al., 2017). System efficiency refers to cropping frequency, crop rotation, livestock density, feed composition, and other indicators of the agricultural system's efficiency at turning inputs into harvestable crops or animal products.

13 Landscape structure denotes landscape elements and their configuration in space (Taylor et al., 1993; Thies and Tscharntke, 1999). This includes different measures of landscape 
complexity, such as number of field trees, hedgerows, field margins, and semi-natural habitat elements, as well as their organization in space (Kleijn et al., 2019). Crop diversity and field size are also components of landscape structure. Depending on the spatial scale of interest, landscape structure may be determined by satellite remote sensing, analysis of aerial photographs, or by mapping in the field. While field tree abundance (Zomer et al., 2016) and field size (Fritz et al., 2015) have been approximated based on satellite imagery, the spatial resolution of underlying data is often too coarse to describe structural characteristics accurately at the spatial scale of agricultural landscapes. Hence, aerial photographs have been the preferred method for analyzing change in landscape structure (Ilhse, 1995; Moser et al., 2002; Persson et al., 2010). In the EU and other European countries, many agrienvironmental schemes aim at maintaining and promoting hedgerows, flower strips, field trees (Kleijn et al., 2006). Beside the simple presence of landscape structure, the quality of landscape elements—what they are and how they are managed—is important for biodiversity and other sustainability outcomes (Smart et al., 2006; Vanbergen et al. this volume; Petit et al. this volume). Capturing the quality of landscape elements often still requires field mapping in addition to aerial photograph analysis (Bailey et al., 2007).

\subsection{Sustainability assessment and trade-offs}

The goal of assessing intensification outcomes is to inform land managers, public offices as well as the scientific community about pathways towards sustainability goals as well as relevant trade-offs (Kanter et al., 2018). Here we rely on the Intergovernmental Platform on Biodiversity and Ecosystem Services (IPBES) for valuing nature's contributions to people (Díaz et al., 2015; Pascual et al., 2017), while applying it to an agricultural context. The first step in this process is identifying sustainability goals that are both relevant for the agricultural land use decision as well as in the respective socio-ecological context (Fig. 3) (Janker and Mann, 2018; Pascual et al., 2017). Sustainability goals should be identified in a participatory manner with various stakeholders groups in the study landscape (Miller et al., 2014). For 
543

example, perceptions of a good quality of life may differ between local stakeholders and

544 state-level policy makers (Zorondo-Rodríguez et al., 2014). The participatory approach early

545 on ensures that multiple value systems are represented in the assessment, and builds a

546 basis of trust important for translating research findings into agronomic practice (Robinson et

547 al., 2011). Sustainability goals may differ based on social and environmental context. For

548 example, preserving soil fertility, having enough to eat, and reducing child labor may be

549 central sustainability goals in a less-developed, small-holder agricultural setting, while

550 improving feed efficiency, decreasing nutrient run-off, and improving animal welfare may be

551 important sustainability goals in an industrialized livestock production setting. Importantly, the

552 selected values should encompass agricultural production and cover all dimensions of 553 sustainability, to ensure comprehensive assessment of trade-offs (Fig. 1).

554

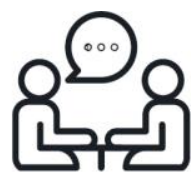

1. Identify relevant sustainability goals

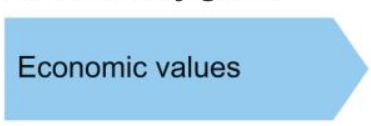

Environmental values

Social values

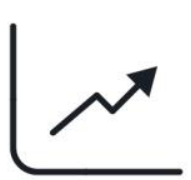

2. Select measurable indicators

Economic indicators

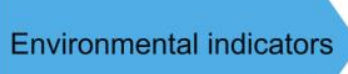

Social indicators

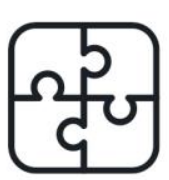

3. Valuation and integration

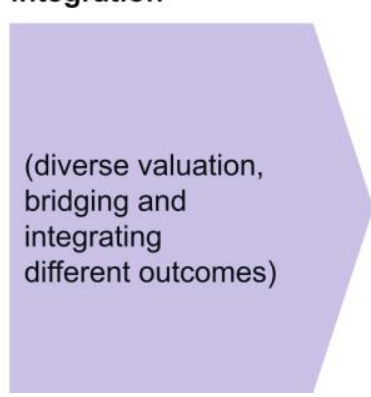

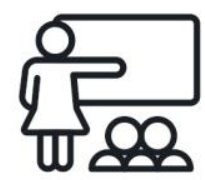

4. Communication of results

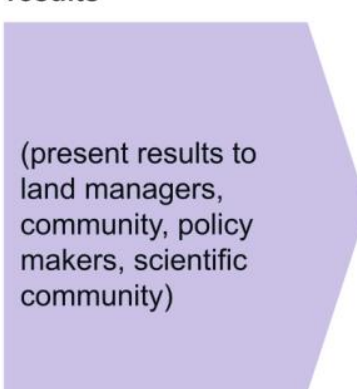

Figure 3. Steps involved in a sustainability assessment of agricultural intensification

557 pathways. The process may be repeated several times, with communication resulting in re-

558 evaluation of relevant sustainability goals.

560 In a second step, measurable indicators are defined to cover the identified sustainability 561 goals (Fig. 3). Based on the sustainability goals selected, this will lead to a large range of 562 indicators both qualitative and quantitative (Van Cauwenbergh et al., 2007). Agricultural 563 production and economic output can usually be measured numerically, and also for many 
564

565

566

567

568

569

570

571

572

573

574

575

576

577 Thirdly, the results of the indicator analysis must be valuated and integrated. One possibility

578 is to calculate economic values of all considered outcomes (de Groot et al., 2002). Economic

579 valuation has the advantage of converting the different physical and social units (e.g. $\mathrm{kg} / \mathrm{ha}$,

580 number of species, landscape scenery preference value) to a single monetary unit, so that

581 they can be aggregated. Such economic valuation has the benefit of crystalizing the 582

583

584

585

586

587

588

589

590

environmental values numerical approximations are possible through measurements and models. For example, to compare sustainability outcomes of agroforestry with arable cropping landscapes in Switzerland, agricultural production, carbon storage, groundwater recharge, habitat protection, nutrient retention, and soil preservation were calculated and modelled considering landscape structure and management intensity (Kay et al., 2018). However, landscape's cultural services and social components of quality of life usually have to be determined qualitatively. For example, in the above case, questionnaires were carried out with local inhabitants to identify the respective landscape's influence on recreation, social relations, aesthetic values, and cultural diversity (Fagerholm et al., 2019). Also, expert judgment may supplant ecological modelling, depending on monetary and time resources and data availability (Kienast and Helfenstein, 2016). For both qualitative and quantitative indicators, confidence levels should be estimated (see Diaz et al., 2019).

valuation outcomes into comprehensive and simple information. Yet, it comes with considerable shortcomings, as some indicators are hard if not impossible to measure in economic terms (Díaz et al., 2015). This is especially true for intrinsic values of nature or quality of life indicators (Pascual et al., 2017). Another option is to present impacts on considered indicators in relation to the reference value (Van Cauwenbergh et al., 2007). For example, in comparing sustainability impacts of organic and conventional agriculture, conventional agriculture is usually taken as the reference, and organic agriculture outcomes are shown in relation to conventional agriculture (Mäder et al., 2002; Seufert and Ramankutty, 2017). Or, pre-defined thresholds may serve as reference values, as in the 
591 planetary boundaries concept (Steffen et al., 2015) or for pollution thresholds (Van

592 Cauwenbergh et al., 2007).

593

594 For both economic transformation and normalization to a reference, it must be decided if 595 outcomes are presented per unit area or per unit agricultural output. This may have 596 considerable impact on the presentation of trade-offs. For example, the benefits of organic 597 farming compared to conventional farming tend to be larger when presented per unit area 598 than per unit agricultural output, due to lower average yields (Seufert and Ramankutty, 599 2017). Decisions taken during valuation and integration can thus have considerable impact 600 on the results, and should be tested by providing different perspectives. Finally, the different 601 spatial and temporal operation scales of outcomes should be considered to address 602 compromises in sustainability at higher spatial scales, or at later points in time (Adger et al., 603 2009).

604

605 Finally, results of the sustainability assessment should be communicated to inform decision 606 making. The results should not only be disseminated in the scientific community through 607 publication and conference presentations, but also disseminated to land managers, the 608 involved communities, and policy makers. Communication can be done in a traditional way of 609 informing the stakeholders (press releases and articles in popular media), but it may also 610 take a more deliberative approach in which the outcomes are leading to a discussion on the 611 values and the options, that can be adapted based on the 'learning' achieved through seeing 612 the results. Communication needs to be transparent and it has to point out uncertainties 613 resulting from data sources and valuation (Pascual et al., 2017).

\section{Potential applications of the framework}

617 We identified three key research themes central for improving the sustainability of agriculture 618 and show how the proposed conceptual framework is useful to address these questions. 
620 A key research theme for improving the sustainability of agriculture is quantifying trade-offs 621 between sustainability and productivity of particular agricultural land use decisions (R1 in Fig.

622 2). While this has been done to illustrate trade-offs between land covers (Foley et al., 2005), 623 it may be done also to illustrate trade-offs between different land use intensities within the 624 same land cover class (Blaser et al., 2018; Mäder et al., 2002). For example, Garbach et al. 625 (2017) reviewed outcomes of five agricultural development strategies (conservation 626 agriculture, precision agriculture, organic farming, holistic grazing management, and system 627 of rice identification) on productivity and nature's contributions to people (Vanbergen et al 628 this volume). Our framework underlines that future research should consider both 629 management intensity and landscape structure to accurately capture sustainability outcome. 630 Future assessments of agricultural development strategies should also incorporate spill-over 631 effects outside of the studied agricultural landscape or in other sustainability dimensions. 632 While many studies have documented management intensity in agricultural landscapes 633 (mostly from the fields of agronomy and biodiversity conservation) and many others have 634 analyzed changes in landscape structure (mostly from the fields of landscape ecology), only 635 few studies have combined the two approaches (Billeter et al., 2008; Geiger et al., 2010). 636 Linking management intensity and landscape structure has provided important insights on 637 biodiversity outcomes (Schneider et al., 2014; Seibold et al., 2019). However, these studies 638 did not consider other outcomes, such as trade-offs with agricultural production or other 639 nature's contributions to people. Future studies will still need to balance the number of 640 indicators that can be considered with available resources; however, attention should be paid 641 to consider effects over multiple dimensions of intensity and sustainability.

643 One of the most important questions for agriculture today is how land managers decide on 644 intensification strategies, and how adoption of sustainable practices can be made more 645 attractive (R2 in Fig. 2). A lot of research has focused on why farmers adopt agroforestry 646 (Sereke et al., 2016), organic farming (Darnhofer et al., 2005; Home et al., 2019), 
conservation agricultural practices (Daloğlu et al., 2014), or precision agriculture (Adrian et al., 2005; Aubert et al., 2012). Land managers' decisions are far more complex than just economic accounting, often they are also affected by perceptions and beliefs, location factors, and (perceived) sustainability outcomes (Adrian et al., 2005; Home et al., 2019). Future studies of historical land system change, and for predicting future adoption of sustainable practices, such as with agent-based modelling, should consider more complex drivers of land use decisions as presented in our framework. A limitation of our proposed approach is that a study needs considerable resources to capture the full complexity of decision making. However, including the full range of factors affecting adoption of sustainable intensification practices is necessary to allow identifying and reducing institutional barriers to adoption (Aubert et al., 2012; Home et al., 2019).

In today's dynamic world of global societal and environmental change, several mega-trends are likely to fundamentally change agricultural land systems (R3 in Fig. 2). For example, how will climate change, smart farming, or increasing demand for renewable energy shape agricultural landscapes? The exponential increase in information and communication technologies (smart farming) is leading to disruptive changes in agricultural practice (Walter et al., 2017), yet it is still largely unknown how this will affect agricultural land system change at the landscape level. Likewise, increasing temperatures and changing precipitation patterns pose new threats and opportunities for crop health, yields, and distribution ranges, in turn affecting local agricultural management and landscape structure (Herzog and Seidl, 2018; Zarrineh et al., 2020). At the same time, the agricultural land sector is expected to play an important role in mitigating climate change by curbing greenhouse gas emissions and sequestering more carbon (Roe et al., 2019). Large-scale implementation of biochar application, agroforestry, bioenergy with carbon capture and storage, and other climatemitigating practices in agriculture are likely to be a main driver of agricultural land system change in the future (Schiermeier, 2019). We argue that these questions should be studied under consideration of location factors and also the social dimension. External mega-trends 
can only lead to sustainable land system change if both physical geography and the social fabric are conducive to the change.

\section{Conclusions}

Agricultural landscapes are under enormous pressure, as food production must not threaten Earth system functioning or social cohesion. This means that future agricultural landscapes need to be viable for farmers, they must accommodate different stakeholder demands in order to be equitable, and their management has to result in lower environmental footprints. In this article we elaborated on the ill-defined term "sustainable intensification" to clearly establish the relevant dimensions and scales that must be considered if a transition to a sustainable agriculture can be achieved. We also provided a conceptual framework to help devise and assess pathways of sustainable agricultural intensification. The novel features of the framework proposed are:

- Defining sustainable intensification as a pathway

- Including conceptual linkages from decision making processes all the way to assessment of sustainability outcomes

- A nested design to account for multiple scales, emphasizing the importance of interactions between farm and landscape levels, and the potential spill-over effects emerging outside them

- Accommodating all three dimensions of sustainability (social, economic, environmental)

- Combining traditional land use intensity analyses focusing on inputs and outputs with assessments of related landscape structures.

With these features, the conceptual framework can help guide research to reconcile food production with sustainability ambitions. 
703

704

\section{Acknowledgements}

706 The authors would like to thank Sandra Gurzeler for help with the figures, Sonja Kay for 707 comments on the manuscript, and Adam Vanbergen and David Bohan for editing the special 708 issue. We would also like to thank Eirini Skrimizea and an anonymous reviewer for 709 exceptionally careful and constructive reviews. The framework proposed has been 710 developed in the project "What is Sustainable Intensification? Operationalizing Sustainable 711 Agricultural Pathways in Europe (SIPATH)", funded by the Swiss National Science 712 Foundation (grant nr. CRSII5_183493) and contributes to the Global Land Programme (GLP) 713 science plan.

714

715

716 


\section{References}

Adger, W.N., Eakin, H., Winkels, A., 2009. Nested and teleconnected vulnerabilities to environmental change. Front. Ecol. Environ. 7, 150-157. https://doi.org/10.1890/070148

Adrian, A.M., Norwood, S.H., Mask, P.L., 2005. Producers' perceptions and attitudes toward precision agriculture technologies. Comput. Electron. Agric. 48, 256-271. https://doi.org/https://doi.org/10.1016/j.compag.2005.04.004

Ajzen, I., 1991. The theory of planned behavior. Organ. Behav. Hum. Decis. Process. 50, 179-211.

Andres, C., Bhullar, G.S., 2016. Sustainable intensification of tropical agro-ecosystems: Need and potentials. Front. Environ. Sci. 4, 1-10. https://doi.org/10.3389/fenvs.2016.00005

Aubert, B.A., Schroeder, A., Grimaudo, J., 2012. IT as enabler of sustainable farming: An empirical analysis of farmers' adoption decision of precision agriculture technology. $\begin{array}{llll}\text { Decis. } & \text { Support } & \text { Syst. } & 540-520 .\end{array}$ https://doi.org/https://doi.org/10.1016/j.dss.2012.07.002

Baessler, C., Klotz, S., 2006. Effects of changes in agricultural land-use on landscape structure and arable weed vegetation over the last 50 years. Agric. Ecosyst. Environ. 115, 43-50. https://doi.org/10.1016/j.agee.2005.12.007

Bailey, D., Herzog, F., Augenstein, I., Aviron, S., Billeter, R., Szerencsits, E., Baudry, J., 2007. Thematic resolution matters: Indicators of landscape pattern for European agroecosystems. Ecol. Indic. 7, 692-709. https://doi.org/10.1016/j.ecolind.2006.08.001

Baumgart-Getz, A., Prokopy, L.S., Floress, K., 2012. Why farmers adopt best management practice in the United States: A meta-analysis of the adoption literature. J. Environ. Manage. 96, 17-25. https://doi.org/https://doi.org/10.1016/j.jenvman.2011.10.006

Billeter, R., Liira, J., Bailey, D., Bugter, R., Arens, P., Augenstein, I., Aviron, S., Baudry, J., Bukacek, R., Burel, F., Cerny, M., De Blust, G., De Cock, R., Diekötter, T., Dietz, H., Dirksen, J., Dormann, C., Durka, W., Frenzel, M., Hamersky, R., Hendrickx, F., Herzog, 
F., Klotz, S., Koolstra, B., Lausch, A., Le Coeur, D., Maelfait, J.P., Opdam, P., Roubalova, M., Schermann, A., Schermann, N., Schmidt, T., Schweiger, O., Smulders, M.J.M.J.M.M., Speelmans, M., Simova, P., Verboom, J., Van Wingerden, W.K.R.E.K.R.E.R.E., Zobel, M., Edwards, P.J.J., 2008. Indicators for biodiversity in agricultural landscapes: A pan-European study. J. Appl. Ecol. 45, 141-150. https://doi.org/10.1111/j.1365-2664.2007.01393.x

Blaser, W.J., Oppong, J., Hart, S.P., Landolt, J., Yeboah, E., Six, J., 2018. Climate-smart sustainable agriculture in low-to-intermediate shade agroforests. Nat. Sustain. 1, 234239. https://doi.org/10.1038/s41893-018-0062-8

BLW, 2019. Agrarbericht: Finanzielle Mittel für Direktzahlungen. Bern.

Bürgi, M., Ali, P., Chowdhury, A., Heinimann, A., Hett, C., Kienast, F., Mondal, M.K., Upreti, B.R., Verburg, P.H., 2017a. Integrated landscape approach: Closing the gap between theory and application. Sustainability 9, 1371. https://doi.org/10.3390/su9081371

Bürgi, M., Bieling, C., von Hackwitz, K., Kizos, T., Lieskovský, J., Martín, M.G., McCarthy, S., Müller, M., Palang, H., Plieninger, T., Printsmann, A., 2017b. Processes and driving forces in changing cultural landscapes across Europe. Landsc. Ecol. 32, 2097-2112. https://doi.org/10.1007/s10980-017-0513-z

Bürgi, M., Hersperger, A.M., Schneeberger, N., 2005. Driving forces of landscape change Current and new directions. Landsc. Ecol. 19, 857-868. https://doi.org/10.1007/s10980005-0245-3

Caron, P., Ferrero y de Loma-Osorio, G., Nabarro, D., Hainzelin, E., Guillou, M., Andersen, I., Arnold, T., Astralaga, M., Beukeboom, M., Bickersteth, S., Bwalya, M., Caballero, P., Campbell, B.M., Divine, N., Fan, S., Frick, M., Friis, A., Gallagher, M., Halkin, J.P., Hanson, C., Lasbennes, F., Ribera, T., Rockstrom, J., Schuepbach, M., Steer, A., Tutwiler, A., Verburg, G., 2018. Food systems for sustainable development: proposals for a profound four-part transformation. Agron. Sustain. Dev. 38. https://doi.org/10.1007/s13593-018-0519-1

Ceddia, M.G., Sedlacek, S., Bardsley, N.O., Gomez-y-Paloma, S., 2013. Sustainable 

agricultural intensification or Jevons paradox? The role of public governance in tropical South America. Glob. Environ. Chang. 23, 1052-1063. https://doi.org/10.1016/j.gloenvcha.2013.07.005

Chen, X., Cui, Z., Fan, M., Vitousek, P., Zhao, M., Ma, W., Wang, Zhenlin, Zhang, Weijian, Yan, X., Yang, J., Deng, X., Gao, Q., Zhang, Q., Guo, S., Ren, J., Li, S., Ye, Y., Wang, Zhaohui, Huang, J., Tang, Q., Sun, Y., Peng, X., Zhang, J., He, M., Zhu, Y., Xue, J., Wang, G., Wu, Liang, An, N., Wu, Liangquan, Ma, L., Zhang, Weifeng, Zhang, F., 2014. Producing more grain with lower environmental costs. Nature 514, 486-9. https://doi.org/10.1038/nature13609

Collins, S.L., Carpenter, S.R., Swinton, S.M., Orenstein, D.E., Childers, D.L., Gragson, T.L., Grimm, N.B., Grove, J.M., Harlan, S.L., Kaye, J.P., Knapp, A.K., Kofinas, G.P., Magnuson, J.J., McDowell, W.H., Melack, J.M., Ogden, L. a, Robertson, G.P., Smith, M.D., Whitmer, A.C., 2011. An integrated conceptual framework for long-term socialecological research. Front. Ecol. Environ. 9, 351-357. https://doi.org/10.1890/100068

Daloğlu, I., Nassauer, J.I., Riolo, R.L., Scavia, D., 2014. Development of a farmer typology of agricultural conservation behavior in the American Corn Belt. Agric. Syst. 129, 93-102. https://doi.org/https://doi.org/10.1016/j.agsy.2014.05.007

Darnhofer, I., Schneeberger, W., Freyer, B., 2005. Converting or not converting to organic farming in Austria: Farmer types and their rationale. Agric. Human Values 22, 39-52. https://doi.org/10.1007/s10460-004-7229-9

de Groot, R.S., Wilson, M.A., Boumans, R.M.J., 2002. A typology for the classification, description and valuation of ecosystem functions, goods and services. Ecol. Econ. 41, 393-408. https://doi.org/https://doi.org/10.1016/S0921-8009(02)00089-7

DeFries, R., Rosenzweig, C., 2010. Toward a whole-landscape approach for sustainable land use in the tropics. Proc. Natl. Acad. Sci. 107, 19627-19632. https://doi.org/10.1073/pnas.1011163107

Díaz, S., Demissew, S., Carabias, J., Joly, C., Lonsdale, M., Ash, N., Larigauderie, A., Adhikari, J.R., Arico, S., Báldi, A., Bartuska, A., Baste, I.A., Bilgin, A., Brondizio, E., 
801

802

803

804

805

806

807

808

809

810

811

812

813

814

815

816

817

818

819

820

821

822

823

824

825

826

827

828

Chan, K.M.A., Figueroa, V.E., Duraiappah, A., Fischer, M., Hill, R., Koetz, T., Leadley, P., Lyver, P., Mace, G.M., Martin-Lopez, B., Okumura, M., Pacheco, D., Pascual, U., Pérez, E.S., Reyers, B., Roth, E., Saito, O., Scholes, R.J., Sharma, N., Tallis, H., Thaman, R., Watson, R., Yahara, T., Hamid, Z.A., Akosim, C., Al-Hafedh, Y., Allahverdiyev, R., Amankwah, E., Asah, T.S., Asfaw, Z., Bartus, G., Brooks, A.L., Caillaux, J., Dalle, G., Darnaedi, D., Driver, A., Erpul, G., Escobar-Eyzaguirre, P., Failler, P., Fouda, A.M.M., Fu, B., Gundimeda, H., Hashimoto, S., Homer, F., Lavorel, S., Lichtenstein, G., Mala, W.A., Mandivenyi, W., Matczak, P., Mbizvo, C., Mehrdadi, M., Metzger, J.P., Mikissa, J.B., Moller, H., Mooney, H.A., Mumby, P., Nagendra, H., Nesshover, C., Oteng-Yeboah, A.A., Pataki, G., Roué, M., Rubis, J., Schultz, M., Smith, P., Sumaila, R., Takeuchi, K., Thomas, S., Verma, M., Yeo-Chang, Y., Zlatanova, D., 2015. The IPBES Conceptual Framework - connecting nature and people. Curr. Opin. Environ. Sustain. 14, 1-16. https://doi.org/10.1016/j.cosust.2014.11.002

Díaz, S., Pascual, U., Stenseke, M., Martín-López, B., Watson, R.T., Molnár, Z., Hill, R., Chan, K.M.A., Baste, I.A., Brauman, K.A., Polasky, S., Church, A., Lonsdale, M., Larigauderie, A., Leadley, P.W., van Oudenhoven, A.P.E., van der Plaat, F., Schröter, M., Lavorel, S., Aumeeruddy-Thomas, Y., Bukvareva, E., Davies, K., Demissew, S., Erpul, G., Failler, P., Guerra, C.A., Hewitt, C.L., Keune, H., Lindley, S., Shirayama, Y., 2018. Assessing nature's contributions to people. Science (80-. ). 359, 270-272. https://doi.org/10.1126/science.aap8826

Díaz, S., Settele, J., E.S., E.S.B., Ngo, H.T., Guèze, M., Agard, J., Arneth, A., Balvanera, P., Brauman, K.A., Butchart, S.H.M., Chan, K.M.A., Garibaldi, L.A., Ichii, K., Liu, J., Subramanian, S.M., Midgley, G.F., Miloslavich, P., Molnár, Z., Obura, D., Pfaff, A., Polasky, S., Purvis, A., Razzaque, J., Reyers, B., Chowdhury, R.R., Shin, Y.J., Visseren-Hamakers, I.J., Willis, K.J., Zayas, C.N., 2019. IPBES (2019): Summary for policymakers of the global assessment report on biodiversity and ecosystem services of the Intergovernmental Science-Policy Platform on Biodiversity and Ecosystem Services. Bonn, Germany. https://doi.org/https://doi.org/10.5281/zenodo.3553579 
Eakin, H., DeFries, R., Kerr, S., Lambin, E.F., Liu, J., Marcotullio, P.J., Messerli, P., Reenberg, A., Rueda, X., Swaffield, S.R., Wicke, B., Zimmerer, K., 2014. Significance of telecoupling for exploration of land-use change. Rethink. Glob. L. Use an Urban Era 14, 141-161.

Emmerson, M., Morales, M.B., Oñate, J.J., Batáry, P., Berendse, F., Liira, J., Aavik, T., Guerrero, I., Bommarco, R., Eggers, S., Pärt, T., Tscharntke, T., Weisser, W., Clement, L., Bengtsson, J., 2016. How agricultural intensification affects biodiversity and ecosystem services, in: Advances in Ecological Research. pp. 43-97. https://doi.org/10.1016/bs.aecr.2016.08.005

Engel, S., Pagiola, S., Wunder, S., 2008. Designing payments for environmental services in theory and practice: An overview of the issues. Ecol. Econ. 65, 663-674. https://doi.org/10.1016/j.ecolecon.2008.03.011

Erb, K.-H., Fetzel, T., Haberl, H., Kastner, T., Kroisleitner, C., Lauk, C., Niedertscheider, M., Plutzar, C., 2016. Beyond Inputs and Outputs: Opening the Black-Box of Land-Use Intensity BT - Social Ecology: Society-Nature Relations across Time and Space, in: Haberl, H., Fischer-Kowalski, M., Krausmann, F., Winiwarter, V. (Eds.), . Springer International Publishing, Cham, pp. 93-124. https://doi.org/10.1007/978-3-319-333267_4

Erb, K.-H., Haberl, H., Jepsen, M.R., Kuemmerle, T., Lindner, M., Müller, D., Verburg, P.H., Reenberg, A., 2013. A conceptual framework for analysing and measuring land-use intensity. Curr. Opin. Environ. Sustain. 5, 464-470. https://doi.org/10.1016/j.cosust.2013.07.010

Fagerholm, N., Torralba, M., Moreno, G., Girardello, M., Herzog, F., Aviron, S., Burgess, P., Crous-Duran, J., Ferreiro-Domínguez, N., Graves, A., Hartel, T., Măcicăsan, V., Kay, S., Pantera, A., Varga, A., Plieninger, T., 2019. Cross-site analysis of perceived ecosystem service benefits in multifunctional landscapes. Glob. Environ. Chang. 56, 134-147. https://doi.org/10.1016/j.gloenvcha.2019.04.002

Fielding, K.S., Terry, D.J., Masser, B.M., Hogg, M.A., 2008. Integrating social identity theory 

and the theory of planned behaviour to explain decisions to engage in sustainable $\begin{array}{llllll}\text { agricultural } & \text { practices. } & \mathrm{Br} . & \mathrm{J} & \text { Soc. } & \text { Psychol. 48. }\end{array}$ https://doi.org/10.1348/014466607X206792

Fishbein, M., Ajzen, I., 2010. Predicting and Changing Behavior: The Reasoned Action Approach. Psychology Press, Taylor \& Francis Group, New York.

Foley, J. a, Defries, R., Asner, G.P., Barford, C., Bonan, G., Carpenter, S.R., Chapin, F.S., Coe, M.T., Daily, G.C., Gibbs, H.K., Helkowski, J.H., Holloway, T., Howard, E. a, Kucharik, C.J., Monfreda, C., Patz, J. a, Prentice, I.C., Ramankutty, N., Snyder, P.K., 2005. Global consequences of land use. Science (80-. ). 309, 570-574. https://doi.org/10.1126/science.1111772

Fritz, S., See, L., Mccallum, I., You, L., Bun, A., Moltchanova, E., Duerauer, M., Albrecht, F., Schill, C., Perger, C., Havlik, P., Mosnier, A., Thornton, P., Wood-Sichra, U., Herrero, M., Becker-Reshef, I., Justice, C., Hansen, M., Gong, P., Abdel Aziz, S., Cipriani, A., Cumani, R., Cecchi, G., Conchedda, G., Ferreira, S., Gomez, A., Haffani, M., Kayitakire, F., Malanding, J., Mueller, R., Newby, T., Nonguierma, A., Olusegun, A., Ortner, S., Rajak, D.R., Rocha, J., Schepaschenko, D., Schepaschenko, M., Terekhov, A., Tiangwa, A., Vancutsem, C., Vintrou, E., Wenbin, W., van der Velde, M., Dunwoody, A., Kraxner, F., Obersteiner, M., 2015. Mapping global cropland and field size. Glob. Chang. Biol. 21, 1980-1992. https://doi.org/10.1111/gcb.12838

Gámez-Virués, S., Perović, D.J., Gossner, M.M., Börschig, C., Blüthgen, N., De Jong, H., Simons, N.K., Klein, A.M., Krauss, J., Maier, G., Scherber, C., Steckel, J., Rothenwöhrer, C., Steffan-Dewenter, I., Weiner, C.N., Weisser, W., Werner, M., Tscharntke, T., Westphal, C., 2015. Landscape simplification filters species traits and drives biotic homogenization. Nat. Commun. 6. https://doi.org/10.1038/ncomms9568

Garbach, K., Milder, J.C., DeClerck, F.A.J., Montenegro de Wit, M., Driscoll, L., GemmillHerren, B., 2017. Examining multi-functionality for crop yield and ecosystem services in five systems of agroecological intensification. Int. J. Agric. Sustain. 15, 11-28. https://doi.org/10.1080/14735903.2016.1174810 
885

886

887

888

889

890

891

892

893

894

895

896

897

898

899

900

901

902

903

904

905

906

907

908

909

910

911

912

Geiger, F., de Snoo, G.R., Berendse, F., Guerrero, I., Morales, M.B., Oñate, J.J., Eggers, S., Pärt, T., Bommarco, R., Bengtsson, J., Clement, L.W., Weisser, W.W., Olszewski, A., Ceryngier, P., Hawro, V., Inchausti, P., Fischer, C., Flohre, A., Thies, C., Tscharntke, T., 2010. Landscape composition influences farm management effects on farmland birds in winter: A pan-European approach. Agric. Ecosyst. Environ. 139, 571-577. https://doi.org/10.1016/j.agee.2010.09.018

Geist, H., McConnell, W., Lambin, E.F., Moran, E., Alves, D., Rudel, T., 2006. Causes and Trajectories of Land-Use/Cover Change BT - Land-Use and Land-Cover Change: Local Processes and Global Impacts, in: Lambin, E.F., Geist, H. (Eds.), . Springer Berlin Heidelberg, Berlin, Heidelberg, pp. 41-70. https://doi.org/10.1007/3-540-32202-7_3

Godfray, H.C.J., Beddington, J.R., Crute, I.R., Haddad, L., Lawrence, D., Muir, J.F., Pretty, J., Robinson, S., Thomas, S.M., Toulmin, C., 2010. Food security: The challenge of feeding 9 billion people. Science (80-. ). $327, \quad 812-818$. https://doi.org/10.1126/science.1185383

Groeneveld, J., Müller, B., Buchmann, C.M., Dressler, G., Guo, C., Hase, N., Hoffmann, F., John, F., Klassert, C., Lauf, T., Liebelt, V., Nolzen, H., Pannicke, N., Schulze, J., Weise, H., Schwarz, N., 2017. Theoretical foundations of human decision-making in agentbased land use models - A review. Environ. Model. Softw. 87, 39-48. https://doi.org/https://doi.org/10.1016/j.envsoft.2016.10.008

Gunton, R., Firbank, L., Inman, A., Winter, M., 2015. Defining sustainable intensification and developing metrics with respect to ecosystem services for the SIP research platform, Report for Defra project LM0302 Sustainable Intensification Research Platform Project 2: Opportunities and Risks for Farming and the Environment at Landscape Scales.

Haberl, H., Kastner, T., Schaffartzik, A., Erb, K.-H., 2016. How Far Does the European Union Reach? Analyzing Embodied HANPP BT - Social Ecology: Society-Nature Relations across Time and Space, in: Haberl, H., Fischer-Kowalski, M., Krausmann, F., Winiwarter, V. (Eds.), Human-Environment Interactions. Springer International Publishing, Cham, pp. 349-360. https://doi.org/10.1007/978-3-319-33326-7_16 
913

914

915

916

917

918

919

920

921

922

923

924

925

926

927

928

929

930

931

932

933

934

935

936

937

938

939

940

Helfenstein, J., Kienast, F., 2014. Ecosystem service state and trends at the regional to national level : A rapid assessment. Ecol. Indic. 36, 11-18.

Herzog, F., Seidl, I., 2018. Swiss alpine summer farming: Current status and future development under climate change. Rangel. J. 40, 501-511. https://doi.org/10.1071/RJ18031

Herzog, F., Steiner, B., Bailey, D., Baudry, J., Billeter, R., Bukácek, R., De Blust, G., De Cock, R., Dirksen, J., Dormann, C.F., De Filippi, R., Frossard, E., Liira, J., Schmidt, T., Stöckli, R., Thenail, C., van Wingerden, W., Bugter, R., 2006. Assessing the intensity of temperate European agriculture at the landscape scale. Eur. J. Agron. 24, 165-181. https://doi.org/10.1016/j.eja.2005.07.006

Home, R., Indermuehle, A., Tschanz, A., Ries, E., Stolze, M., 2019. Factors in the decision by Swiss farmers to convert to organic farming. Renew. Agric. Food Syst. 34, 571-581. https://doi.org/DOI: 10.1017/S1742170518000121

Huber, R., Bakker, M., Balmann, A., Berger, T., Bithell, M., Brown, C., Grêt-Regamey, A., Xiong, H., Le, Q.B., Mack, G., Meyfroidt, P., Millington, J., Müller, B., Polhill, J.G., Sun, Z., Seidl, R., Troost, C., Finger, R., 2018. Representation of decision-making in European agricultural agent-based models. Agric. Syst. 167, 143-160. https://doi.org/https://doi.org/10.1016/j.agsy.2018.09.007

Ilhse, M., 1995. Swedish agricultural landscapes--patterns and changes during the last 50 years, studied by aerial photos. Landsc. Urban Plan. 31, 21-37.

Janker, J., Mann, S., 2018. Understanding the social dimension of sustainability in agriculture: a critical review of sustainability assessment tools. Environ. Dev. Sustain. https://doi.org/10.1007/s10668-018-0282-0

Janker, J., Mann, S., Rist, S., 2019. Social sustainability in agriculture - A system-based framework. J. Rural Stud. 65, 32-42. https://doi.org/10.1016/j.jrurstud.2018.12.010

Janker, J., Mann, S., Rist, S., 2018. What is sustainable agriculture? Critical analysis of the international political discourse. Sustainability $10,1-19$. https://doi.org/10.3390/su10124707 
Jepsen, M.R., Kuemmerle, T., Müller, D., Erb, K., Verburg, P.H., Haberl, H., Vesterager, J.P., Andrič, M., Antrop, M., Austrheim, G., Björn, I., Bondeau, A., Bürgi, M., Bryson, J., Caspar, G., Cassar, L.F., Conrad, E., Chromý, P., Daugirdas, V., Van Eetvelde, V., Elena-Rosselló, R., Gimmi, U., Izakovicova, Z., Jančák, V., Jansson, U., Kladnik, D., Kozak, J., Konkoly-Gyuró, E., Krausmann, F., Mander, Ü., McDonagh, J., Pärn, J., Niedertscheider, M., Nikodemus, O., Ostapowicz, K., Pérez-Soba, M., Pinto-Correia, T., Ribokas, G., Rounsevell, M., Schistou, D., Schmit, C., Terkenli, T.S., Tretvik, A.M., Trzepacz, P., Vadineanu, A., Walz, A., Zhllima, E., Reenberg, A., 2015. Transitions in European land-management regimes between 1800 and 2010. Land use policy 49, 5364. https://doi.org/https://doi.org/10.1016/j.landusepol.2015.07.003

Junge, X., Schüpbach, B., Walter, T., Schmid, B., Lindemann-Matthies, P., 2015. Aesthetic quality of agricultural landscape elements in different seasonal stages in Switzerland. Landsc. Urban Plan. 133, 67-77. https://doi.org/10.1016/j.landurbplan.2014.09.010

Kadykalo, A.N., López-Rodriguez, M.D., Ainscough, J., Droste, N., Ryu, H., Ávila-Flores, G., Le Clec'h, S., Muñoz, M.C., Nilsson, L., Rana, S., Sarkar, P., Sevecke, K.J., Harmáčková, Z. V., 2019. Disentangling 'ecosystem services' and 'nature's contributions to people.' Ecosyst. People 15, 269-287. https://doi.org/10.1080/26395916.2019.1669713

Kanter, D.R., Musumba, M., Wood, S.L.R., Palm, C., Antle, J., Balvanera, P., Dale, V.H., Havlik, P., Kline, K.L., Scholes, R.J., Thornton, P., Tittonell, P., Andelman, S., 2018. Evaluating agricultural trade-offs in the age of sustainable development is 163, 73-88. https://doi.org/10.1016/j.agsy.2016.09.010

Kay, S., Crous-Duran, J., García de Jalón, S., Graves, A., Palma, J.H.N., Roces-Díaz, J. V., Szerencsits, E., Weibel, R., Herzog, F., 2018. Landscape-scale modelling of agroforestry ecosystems services in Swiss orchards: a methodological approach. Landsc. Ecol. 33, 1633-1644. https://doi.org/10.1007/s10980-018-0691-3

Kay, S., Graves, A., Palma, J.H.N., Moreno, G., Roces-Díaz, J. V., Aviron, S., Chouvardas, D., Crous-Duran, J., Ferreiro-Domínguez, N., García de Jalón, S., Măcicăşan, V., 
Mosquera-Losada, M.R., Pantera, A., Santiago-Freijanes, J.J., Szerencsits, E., Torralba, M., Burgess, P.J., Herzog, F., 2019. Agroforestry is paying off - Economic evaluation of ecosystem services in European landscapes with and without agroforestry systems. Ecosyst. Serv. 36. https://doi.org/10.1016/j.ecoser.2019.100896

Kienast, F., Helfenstein, J., 2016. Modelling Ecosystem Services, in: Potschin, M., HainesYoung, R., Fish, R., Turner, R.K. (Eds.), Routledge Handbook of Ecosystem Services. Routledge, Milton Park, UK.

Kienast, F., Helfenstein, J., Grêt-Regamey, A., Haines-Young, R., Potschin, M., 2019. Ecosystem Services Under Pressure, in: von Haaren, C., Lovett, A.A., Albert, C. (Eds.), Landscape Planning with Ecosystem Services. Springer Netherlands, Dordrecht, pp. 91-101. https://doi.org/10.1007/978-94-024-1681-7_7

Kleijn, D., Baquero, R.A., Clough, Y., Díaz, M., De Esteban, J., Fernández, F., Gabriel, D., Herzog, F., Holzschuh, A., Jöhl, R., Knop, E., Kruess, A., Marshall, E.J.P., SteffanDewenter, I., Tscharntke, T., Verhulst, J., West, T.M., Yela, J.L., 2006. Mixed biodiversity benefits of agri-environment schemes in five European countries. Ecol. Lett. 9, 243-254. https://doi.org/10.1111/j.1461-0248.2005.00869.x

Kleijn, D., Bommarco, R., Fijen, T.P.M., Garibaldi, L.A., Potts, S.G., van der Putten, W.H., 2019. Ecological Intensification: Bridging the Gap between Science and Practice. Trends Ecol. Evol. 34, 154-166. https://doi.org/10.1016/j.tree.2018.11.002

Kuemmerle, T., Erb, K., Meyfroidt, P., Müller, D., Verburg, P.H., Estel, S., Haberl, H., Hostert, P., Jepsen, M.R., Kastner, T., Levers, C., Lindner, M., Plutzar, C., Verkerk, P.J., van der Zanden, E.H., Reenberg, A., 2013. Challenges and opportunities in mapping land use intensity globally. Curr. Opin. Environ. Sustain. 5, 484-493. https://doi.org/10.1016/j.cosust.2013.06.002

Levers, C., Butsic, V., Verburg, P.H., Müller, D., Kuemmerle, T., 2016. Drivers of changes in agricultural intensity in Europe. Land use policy 58, 380-393. https://doi.org/10.1016/j.landusepol.2016.08.013

Levers, C., Müller, D., Erb, K., Haberl, H., Jepsen, M.R., Metzger, M.J., Meyfroidt, P., 
Plieninger, T., Plutzar, C., Stürck, J., Verburg, P.H., Verkerk, P.J., Kuemmerle, T., 2018. Archetypical patterns and trajectories of land systems in Europe. Reg. Environ. Chang. 18, 715-732. https://doi.org/10.1007/s10113-015-0907-x

Liu, J., Hull, V., Batistella, M., Defries, R., Dietz, T., Fu, F., Hertel, T.W., Cesar, R., Lambin, E.F., Li, S., Martinelli, L.A., Mcconnell, W.J., Moran, E.F., Naylor, R., 2013. Framing Sustainability in a Telecoupled World 18.

Mäder, P., Fliessbach, A., Dubois, D., Gunst, L., Fried, P., Niggli, U., Maeder, P., Fliessbach, A., Dubois, D., Gunst, L., Fried, P., Niggli, U., 2002. Soil fertility and biodiversity in organic farming. Science (80-. $) . \quad 296, \quad 1694-1697$. https://doi.org/10.1126/science.1071148

Magliocca, N.R., Ellis, E.C., Allington, G.R.H., Bremond, A. De, Dell, J., Mertz, O., Messerli, P., Meyfroidt, P., Seppelt, R., Verburg, P.H., 2018. Closing global knowledge gaps: Producing generalized knowledge from case studies of social-ecological systems. Glob. Environ. Chang. 50, 1-14. https://doi.org/10.1016/j.gloenvcha.2018.03.003

Mahon, N., Crute, I., Simmons, E., Islam, M.M., 2017. Sustainable intensification "oxymoron" or "third-way"? A systematic review. Ecol. Indic. 74, 73-97. https://doi.org/10.1016/j.ecolind.2016.11.001

Malaj, E., Von Der Ohe, P.C., Grote, M., Kühne, R., Mondy, C.P., Usseglio-Polatera, P., Brack, W., Schäfer, R.B., 2014. Organic chemicals jeopardize the health of freshwater ecosystems on the continental scale. Proc. Natl. Acad. Sci. U. S. A. 111, 9549-9554. https://doi.org/10.1073/pnas.1321082111

Malek, Ž., Douw, B., Van Vliet, J., Van Der Zanden, E.H., Verburg, P.H., 2019. Local landuse decision-making in a global context. Environ. Res. Lett. 14, 83006. https://doi.org/10.1088/1748-9326/ab309e

Mann, S., 2018. Socioeconomics of Agriculture, SpringerBriefs in Economics. Springer Open, Cham, Switzerland.

Meiyappan, P., Roy, P.S., Sharma, Y., Ramachandran, R.M., Joshi, P.K., DeFries, R.S., Jain, A.K., 2017. Dynamics and determinants of land change in India: integrating 
Submitted manuscript Helfenstein et al. (2020) https://doi.org/10.1016/bs.aecr.2020.08.005

1025

1026

1027

1028

1029

1030

1031

1032

1033

1034

1035

1036

1037

1038

1039

1040

1041

1042

1043

1044

1045

1046

1047

1048

1049

1050

1051

1052

satellite data with village socioeconomics. Reg. Environ. Chang. 17, 753-766. https://doi.org/10.1007/s10113-016-1068-2

Meyfroidt, P., 2016. Approaches and terminology for causal analysis in land systems $\begin{array}{lllll}\text { science. } & \text { J. Und } & \text { Land }\end{array}$ https://doi.org/10.1080/1747423X.2015.1117530

Meyfroidt, P., Roy Chowdhury, R., de Bremond, A., Ellis, E.C., Erb, K.-H., Filatova, T., Garrett, R.D., Grove, J.M., Heinimann, A., Kuemmerle, T., Kull, C.A., Lambin, E.F., Landon, Y., le Polain de Waroux, Y., Messerli, P., Müller, D., Nielsen, J.Ø., Peterson, G.D., Rodriguez García, V., Schlüter, M., Turner, B.L., Verburg, P.H., 2018. Middlerange theories of land system change. Glob. Environ. Chang. 53, 52-67. https://doi.org/10.1016/J.GLOENVCHA.2018.08.006

Millennium Ecosystem Assessment, 2005. Ecosystems and Human Well-being: Biodiversity Synthesis. Washington, DC.

Miller, T.R., Wiek, A., Sarewitz, D., Robinson, J., Olsson, L., Kriebel, D., Loorbach, D., 2014. The future of sustainability science: A solutions-oriented research agenda. Sustain. Sci. 9, 239-246. https://doi.org/10.1007/s11625-013-0224-6

Moser, D., Zechmeister, H.G., Plutzar, C., Sauberer, N., Wrbka, T., Grabherr, G., 2002. Landscape patch shape complexity as an effective measure for plant species richness in rural landscapes. Landsc. Ecol. 17, 657-669. https://doi.org/10.1023/A:1021513729205

Müller-Hansen, F., Schlüter, M., Mäs, M., Donges, J.F., Kolb, J.J., Thonicke, K., Heitzig, J., 2017. Towards representing human behavior and decision making in Earth system models - an overview of techniques and approaches. Earth Syst. Dynam. 8, 977-1007. https://doi.org/10.5194/esd-8-977-2017

Noss, R.F., 1983. A Regional Landscape Approach to Maintain Diversity. Bioscience 33, 700-706. https://doi.org/10.2307/1309350

Oehri, J., Schmid, B., Schaepman-Strub, G., Niklaus, P.A., 2020. Terrestrial land-cover type richness is positively linked to landscape-level functioning. Nat. Commun. 11, 1-10. 
1053

1054

1055

1056

1057

1058

1059

1060

1061

1062

1063

1064

1065

1066

1067

1068

1069

1070

1071

1072

1073

1074

1075

1076

1077

1078

1079

1080 https://doi.org/10.1038/s41467-019-14002-7

Pascual, U., Balvanera, P., Díaz, S., Pataki, G., Roth, E., Stenseke, M., Watson, R.T., Başak Dessane, E., Islar, M., Kelemen, E., Maris, V., Quaas, M., Subramanian, S.M., Wittmer, H., Adlan, A., Ahn, S.E., Al-Hafedh, Y.S., Amankwah, E., Asah, S.T., Berry, P., Bilgin, A., Breslow, S.J., Bullock, C., Cáceres, D., Daly-Hassen, H., Figueroa, E., Golden, C.D., Gómez-Baggethun, E., González-Jiménez, D., Houdet, J., Keune, H., Kumar, R., Ma, K., May, P.H., Mead, A., O'Farrell, P., Pandit, R., Pengue, W., Pichis-Madruga, R., Popa, F., Preston, S., Pacheco-Balanza, D., Saarikoski, H., Strassburg, B.B., van den Belt, M., Verma, M., Wickson, F., Yagi, N., 2017. Valuing nature's contributions to people: the IPBES approach. Curr. Opin. Environ. Sustain. 26-27, 7-16. https://doi.org/10.1016/j.cosust.2016.12.006

Persson, A.S., Olsson, O., Rundlöf, M., Smith, H.G., 2010. Land use intensity and landscape complexity-Analysis of landscape characteristics in an agricultural region in Southern Sweden.

Agric.

Ecosyst.

Environ.

136 ,

$169-176$.

https://doi.org/10.1016/j.agee.2009.12.018

Pfund, J.-L., 2010. Landscape-scale research for conservation and development in the tropics: fighting persisting challenges. Curr. Opin. Environ. Sustain. 2, 117-126. https://doi.org/https://doi.org/10.1016/j.cosust.2010.03.002

Plieninger, T., Draux, H., Fagerholm, N., Bieling, C., Bürgi, M., Kizos, T., Kuemmerle, T., Primdahl, J., Verburg, P.H., 2016. The driving forces of landscape change in Europe: A systematic review of the evidence. Land use policy 57, 204-214. https://doi.org/10.1016/j.landusepol.2016.04.040

Prestele, R., Verburg, P.H., 2019. The overlooked spatial dimension of climate-smart agriculture. Glob. Chang. Biol. https://doi.org/10.1111/gcb.14940

Pretty, J., Toulmin, C., Williams, S., 2011. Sustainable intensification in African agriculture. Int. J. Agric. Sustain. 9, 5-24. https://doi.org/10.3763/ijas.2010.0583

Pretty, J.N., 1997. The sustainable intensification of agriculture. Nat. Resour. Forum 21, 247-256. https://doi.org/10.1111/j.1477-8947.1997.tb00699.x 
1081

1082

1083

1084

1085

1086

1087

1088

1089

1090

1091

1092

1093

1094

1095

1096

1097

1098

1099

1100

1101

1102

1103

1104

1105

1106

1107

1108

Prishchepov, A. V, Müller, D., Dubinin, M., Baumann, M., Radeloff, V.C., 2013. Determinants of agricultural land abandonment in post-Soviet European Russia. Land use policy 30, 873-884. https://doi.org/https://doi.org/10.1016/j.landusepol.2012.06.011

Rasmussen, L.V., Coolsaet, B., Martin, A., Mertz, O., Pascual, U., Corbera, E., Dawson, N., Fisher, J.A., Franks, P., Ryan, C.M., 2018. Social-ecological outcomes of agricultural intensification. Nat. Sustain. 1, 275-282. https://doi.org/10.1038/s41893-018-0070-8

Robinson, J., Burch, S., Talwar, S., O'Shea, M., Walsh, M., 2011. Envisioning sustainability: Recent progress in the use of participatory backcasting approaches for sustainability research. Technol. Forecast. Soc. Change 78, 756-768. https://doi.org/https://doi.org/10.1016/j.techfore.2010.12.006

Rockström, J., Williams, J., Daily, G., Noble, A., Matthews, N., Gordon, L., Wetterstrand, H., DeClerck, F., Shah, M., Steduto, P., de Fraiture, C., Hatibu, N., Unver, O., Bird, J., Sibanda, L., Smith, J., 2017. Sustainable intensification of agriculture for human prosperity and global sustainability. Ambio 46, 4-17. https://doi.org/10.1007/s13280016-0793-6

Roe, S., Lawrence, D., Streck, C., Obersteiner, M., Frank, S., Griscom, B., Gusti, M., Harris, N., Hausfather, Z., Havlík, P., House, J., Nabuurs, G.-J., Sánchez, M.J.S., Sanderman, J., Smith, P., 2019. Contribution of the land sector to a $1.5^{\circ} \mathrm{C}$ World. Nat. Clim. Chang. 9, 817-828. https://doi.org/10.1038/s41558-019-0591-9

Sayer, J., Sunderland, T., Ghazoul, J., Pfund, J.-L., Sheil, D., Meijaard, E., Venter, M., Boedhihartono, A.K., Day, M., Garcia, C., van Oosten, C., Buck, L.E., 2013. Ten principles for a landscape approach to reconciling agriculture, conservation, and other competing land uses. Proc. Natl. Acad. Sci. U. S. A. 110, 8349-8356. https://doi.org/10.1073/pnas.1210595110

Schiermeier, Q., 2019. New EU chief makes bold climate pledges. Nature. https://doi.org/10.1038/d41586-019-02204-4

Schlüter, M., Baeza, A., Dressler, G., Frank, K., Groeneveld, J., Jager, W., Janssen, M.A., McAllister, R.R.J., Müller, B., Orach, K., Schwarz, N., Wijermans, N., 2017. A framework 

for mapping and comparing behavioural theories in models of social-ecological systems. Ecol. Econ. 131, 21-35. https://doi.org/https://doi.org/10.1016/j.ecolecon.2016.08.008

Schmitzberger, I., Wrbka, T., Steurer, B., Aschenbrenner, G., Peterseil, J., Zechmeister, H.G., 2005. How farming styles influence biodiversity maintenance in Austrian agricultural landscapes. Agric. Ecosyst. Environ. 108, 274-290. https://doi.org/https://doi.org/10.1016/j.agee.2005.02.009

Schneider, F., Kläy, A., Zimmermann, A.B., Buser, T., Ingalls, M., Messerli, P., 2019. How can science support the 2030 Agenda for Sustainable Development? Four tasks to tackle the normative dimension of sustainability. Sustain. Sci. 14, 1593-1604. https://doi.org/10.1007/s11625-019-00675-y

Schneider, M.K., Lüscher, G., Jeanneret, P., Arndorfer, M., Ammari, Y., Bailey, D., Balázs, K., Báldi, A., Choisis, J.P., Dennis, P., Eiter, S., Fjellstad, W., Fraser, M.D., Frank, T., Friedel, J.K., Garchi, S., Geijzendorffer, I.R., Gomiero, T., Gonzalez-Bornay, G., Hector, A., Jerkovich, G., Jongman, R.H.G., Kakudidi, E., Kainz, M., Kovács-Hostyánszki, A., Moreno, G., Nkwiine, C., Opio, J., Oschatz, M.L., Paoletti, M.G., Pointereau, P., Pulido, F.J., Sarthou, J.P., Siebrecht, N., Sommaggio, D., Turnbull, L.A., Wolfrum, S., Herzog, F., 2014. Gains to species diversity in organically farmed fields are not propagated at the farm level. Nat. Commun. 5, 1-9. https://doi.org/10.1038/ncomms5151

Schüpbach, B., Roesch, A., Herzog, F., Szerencsits, E., Walter, T., 2020. Development and application of indicators for visual landscape quality to include in life cycle sustainability assessment of Swiss agricultural farms. Ecol. Indic. 110, 105788. https://doi.org/10.1016/j.ecolind.2019.105788

Searchinger, T., Waite, R., Hanson, C., Ranganathan, J., Dumas, P., Matthews, E., 2018. Creating a sustainable food future: synthesis report.

Seibold, S., Gossner, M.M., Simons, N.K., Blüthgen, N., Ambarl, D., Ammer, C., Bauhus, J., Fischer, M., Habel, C., Linsenmair, K.E., Nauss, T., Penone, C., 2019. Arthropod decline in grasslands and forests is associated with drivers at landscape level. Nature 574, 1-34. https://doi.org/10.1038/s41586-019-1684-3 
Sereke, F., Dobricki, M., Wilkes, J., Kaeser, A., Graves, A.R., Szerencsits, E., Herzog, F., 2016. Swiss farmers don't adopt agroforestry because they fear for their reputation. Agrofor. Syst. 90, 385-394. https://doi.org/10.1007/s10457-015-9861-3

Seufert, V., Ramankutty, N., 2017. Many shades of gray-the context-dependent performance of organic agriculture. Sci. Adv. 3. https://doi.org/10.1126/sciadv.1602638

Singh, L., Bhangoo, K., Sharma, R., 2020. Agrarian Distress and Farmer Suicides in North India. Routledge, London. https://doi.org/https://doi.org/10.4324/9780429270628

Smart, S.M., Marrs, R.H., Le Duc, M.G., Thompson, K.E.N., Bunce, R.G.H., Firbank, L.E.S.G., Rossall, M.J., 2006. Spatial relationships between intensive land cover and residual plant species diversity in temperate farmed landscapes. J. Appl. Ecol. 43, 1128-1137. https://doi.org/10.1111/j.1365-2664.2006.01231.x

Smith, A., Snapp, S., Chikowo, R., Thorne, P., Bekunda, M., Glover, J., 2017. Measuring sustainable intensification in smallholder agroecosystems: A review. Glob. Food Sec. 12, 127-138. https://doi.org/10.1016/j.gfs.2016.11.002

Steffen, W., Richardson, K., Rockstrom, J., Cornell, S.E., Fetzer, I., Bennett, E.M., Biggs, R., Carpenter, S.R., de Vries, W., de Wit, C.A., Folke, C., Gerten, D., Heinke, J., Mace, G.M., Persson, L.M., Ramanathan, V., Reyers, B., Sorlin, S., 2015. Planetary boundaries: Guiding human development on a changing planet. Science (80-. ). 347, 1259855. https://doi.org/10.1126/science.1259855

Stoate, C., Baldi, A., Beja, P., Boatman, N.D., Herzon, I., Doorn, A. Van, Snoo, G.R. De, Rakosy, L., Ramwell, C., 2009. Ecological impacts of early 21 st century agricultural change in Europe - A review 91, 22-46. https://doi.org/10.1016/j.jenvman.2009.07.005

Stokstad, E., 2019. Nitrogen crisis from jam-packed livestock operations has 'paralyzed' Dutch economy. Science (80-. ). https://doi.org/doi:10.1126/science.aba4504

Struik, P.C., Kuyper, T.W., 2017. Sustainable intensification in agriculture: the richer shade of green. A review. Agron. Sustain. Dev. 37. https://doi.org/10.1007/s13593-017-0445-7

Struik, P.C., Kuyper, T.W., Brussaard, L., Leeuwis, C., 2014. Deconstructing and unpacking scientific controversies in intensification and sustainability: why the tensions in concepts 
Submitted manuscript Helfenstein et al. (2020) https://doi.org/10.1016/bs.aecr.2020.08.005

and values? Curr. Opin. Environ. Sustain. 8, 80-88. https://doi.org/https://doi.org/10.1016/j.cosust.2014.10.002

Taylor, P.D., Fahrig, L., Henein, K., Merriam, G., 1993. Connectivity Is a Vital Element of Landscape Structure. Oikos 68, 571-573.

Thies, C., Tscharntke, T., 1999. Landscape structure and biological control in $\begin{array}{llll}\text { agroecosystems. } & \text { Science } & \text { (80-. } & \text { 893-895. }\end{array}$ https://doi.org/10.1126/science.285.5429.893

Tittonell, P., 2014. Ecological intensification of agriculture-sustainable by nature. Curr. Opin. Environ. Sustain. 8, 53-61. https://doi.org/10.1016/j.cosust.2014.08.006

Tscharntke, T., Klein, A.M., Kruess, A., Steffan-Dewenter, I., Thies, C., 2005. Landscape perspectives on agricultural intensification and biodiversity - Ecosystem service management. Ecol. Lett. 8, 857-874. https://doi.org/10.1111/j.1461-0248.2005.00782.x

Valbuena, D., Verburg, P.H., Bregt, A.K., 2008. A method to define a typology for agentbased analysis in regional land-use research. Agric. Ecosyst. Environ. 128, 27-36. https://doi.org/https://doi.org/10.1016/j.agee.2008.04.015

Van Cauwenbergh, N., Biala, K., Bielders, C., Brouckaert, V., Franchois, L., Garcia Cidad, V., Hermy, M., Mathijs, E., Muys, B., Reijnders, J., Sauvenier, X., Valckx, J., Vanclooster, M., Van der Veken, B., Wauters, E., Peeters, A., 2007. SAFE-A hierarchical framework for assessing the sustainability of agricultural systems. Agric. Ecosyst. Environ. 120, 229-242. https://doi.org/10.1016/j.agee.2006.09.006

van Vliet, J., de Groot, H.L., Rietveld, P., Verburg, P.H., 2015. Manifestations and underlying drivers of agricultural land use change in Europe. Landsc. Urban Plan. 133, 24-36.

Van Zanten, B.T., Verburg, P.H., Espinosa, M., Gomez-Y-Paloma, S., Galimberti, G., Kantelhardt, J., Kapfer, M., Lefebvre, M., Manrique, R., Piorr, A., Raggi, M., Schaller, L., Targetti, S., Zasada, I., Viaggi, D., 2014. European agricultural landscapes, common agricultural policy and ecosystem services: A review. Agron. Sustain. Dev. 34, 309-325. https://doi.org/10.1007/s13593-013-0183-4

Verburg, P.H., Crossman, N., Ellis, E.C., Heinimann, A., Hostert, P., Mertz, O., Nagendra, H., 
1193

1194

1195

1196

1197

1198

1199

1200

1201

1202

1203

1204

1205

1206

1207

1208

1209

1210

1211

1212

1213

1214

1215

1216

1217

1218

1219

1220

Sikor, T., Erb, K.H., Golubiewski, N., Grau, R., Grove, M., Konaté, S., Meyfroidt, P., Parker, D.C., Chowdhury, R.R., Shibata, H., Thomson, A., Zhen, L., 2015. Land system science and sustainable development of the earth system: A global land project perspective. Anthropocene 12. https://doi.org/10.1016/j.ancene.2015.09.004

Verburg, P.H., Erb, K.H., Mertz, O., Espindola, G., 2013. Land System Science: Between global challenges and local realities. Curr. Opin. Environ. Sustain. 5, 433-437. https://doi.org/10.1016/j.cosust.2013.08.001

von Haaren, C., Kempa, D., Vogel, K., Rüter, S., 2012. Assessing biodiversity on the farm scale as basis for ecosystem service payments. J. Environ. Manage. 113, 40-50. https://doi.org/https://doi.org/10.1016/j.jenvman.2012.07.033

Walter, A., Finger, R., Huber, R., Buchmann, N., 2017. Smart farming is key to developing sustainable agriculture. Proc. Natl. Acad. Sci. U. S. A. 114, 6148-6150. https://doi.org/10.1073/pnas.1707462114

Wauters, E., Bielders, C., Poesen, J., Govers, G., Mathijs, E., 2010. Adoption of soil conservation practices in Belgium: An examination of the theory of planned behaviour in the agri-environmental domain. Land use policy 27, 86-94. https://doi.org/https://doi.org/10.1016/j.landusepol.2009.02.009

Weltin, M., Zasada, I., Piorr, A., Debolini, M., Geniaux, G., Moreno Perez, O., Scherer, L., Tudela Marco, L., Schulp, C.J.E., 2018. Conceptualising fields of action for sustainable intensification - A systematic literature review and application to regional case studies. Agric. Ecosyst. Environ. 257, 68-80. https://doi.org/10.1016/j.agee.2018.01.023

Xavier, 2018. Institut du développement durable et des relations internationales An agroecological Europe in 2050: multifunctional agriculture for healthy eating Findings from the Ten Years For Agroecology (TYFA) modelling exercise.

Zarrineh, N., Abbaspour, K.C., Holzkämper, A., 2020. Integrated assessment of climate change impacts on multiple ecosystem services in Western Switzerland. Sci. Total Environ. 708, 135212. https://doi.org/10.1016/j.scitotenv.2019.135212

Zomer, R.J., Neufeldt, H., Xu, J., Ahrends, A., Bossio, D., Trabucco, A., Van Noordwijk, M., 

Wang, M., 2016. Global Tree Cover and Biomass Carbon on Agricultural Land: The contribution of agroforestry to global and national carbon budgets. Sci. Rep. 6, 1-12. https://doi.org/10.1038/srep29987

1224 Zorondo-Rodríguez, F., Gómez-Baggethun, E., Demps, K., Ariza-Montobbio, P., García, C., 1225 Reyes-García, V., 2014. What Defines Quality of Life? The Gap Between Public Policies 1226 and Locally Defined Indicators Among Residents of Kodagu, Karnataka (India). Soc. Indic. Res. 115, 441-456. https://doi.org/10.1007/s11205-012-9993-z

1228 